\title{
Towards understanding the role of sialylation in melanoma progression
}

\author{
Ewa Kolasińska, Małgorzata Przybyło ${ }^{\bowtie}$, Marcelina Janik and Anna Lityńska \\ Department of Glycoconjugate Biochemistry, Jagiellonian University in Krakow, Kraków, Poland
}

\begin{abstract}
Aberrant expression of sialic acids or altered linkage types is closely associated with malignant phenotype and metastatic potential, and can have prognostic significance in human cancer. The present study was undertaken to evaluate whether expression of sialylated derivatives on melanoma cell surface is associated with tumour progression. Four cell lines (WM1552C, WM115, IGR-39 and WM266-4) were used in the study. Cell surface expression of sialic acids was evaluated by flow cytometry with the use of Maackia amurensis and Sambucus nigra lectins. Moreover, adhesion and migration potential of melanoma cells and involvement of sialic acids in these processes were analysed. We have demonstrated that WM266-4 cells have a significantly higher level of a2,3-linked sialic acid residues than other cells, whereas IGR-39 cells had lower expression of a2,6linked sialic acids. The adhesion efficiencies of WM1552C and WM115 cells were significantly lower than that of IGR-39 and WM266-4 cells. In contrast, WM266-4 cells repaired scratch wounds at least twice as fast as other cells. Melanoma cell adhesion to fibronectin in the presence of Sambucus nigra agglutinin (SNA) was reduced only in IGR-39 and WM266-4 cells, whereas the impact of Maackia amurensis agglutinin (MAA) on this process was much more important. Migration efficiency of melanoma cells was reduced more strongly in the presence of MAA than SNA. In conclusion, our results show that melanoma progression is associated with the increased expression of a2,3-linked sialic acids on the cell surface and these residues could promote melanoma cell interaction with fibronectin.
\end{abstract}

Key words: integrins, lectins, melanoma, progression, sialic acids, sialylation

Received: 24 November, 2015; revised: 23 May, 2016; accepted: 25 May, 2016; available on-line: 30 July, 2016

\section{INTRODUCTION}

The incidence of cutaneous malignant melanoma is increasing more rapidly than that of any other tumours. Additionally, due to high capability of invasion, rapid metastasis and resistance to conventional therapies, melanoma is one of the most lethal malignancies among human cancers (Gallagher et al., 2005). Based on clinical and histopathological features, five distinct steps have been proposed for the progression of human cutaneous malignant melanoma: i) common nevi with structurally normal melanocytes; ii) dysplastic nevi with atypia (precursors of melanoma); iii) radial growth phase (RGP) - primary melanoma in which cells have not yet metastasized; iv) advance vertical growth phase (VGP) - primary melanoma in which cells have invaded the dermis and have the potential to metastasize; v) metastatic melanoma (Li \& Herlyn, 2000). The transition from the RGP to VGP is a critical step during tumour progression. Melanoma cells in VGP have the competence to invade the dermis and subsequently metastasize, while in RGP they do not (Sturm et al., 2002). During acquisition of the invasive phenotype altered cell-cell and cell-ECM interactions are critical factors (Ruiter \& Muijen, 1998). Most of the cancer cell surface adhesion proteins, which are the principal regulators of adhesion and migration, are glycosylated, and modulation of adhesion receptor $\mathrm{N}$-oligosaccharides have been found to significantly alter their biological functions including cell spreading, migration as well as signal transduction (Couldrey \& Green, 2000; Nadanaka et al., 2001; Guo et al., 2002; Pocheć et al., 2003; Bellis, 2004; Gu \& Taniguchi, 2008; Przybyło et al., 2008; Pocheć et al., 2013; Janik et al., 2014; Pocheć et al., 2015).

The most frequently observed alterations during tumorigenesis include extensive expression of $\beta 1-6$ branched complex type N-glycans (Guo et al., 2000; Ochwat et al., 2004; Zhang et al., 2004; Przybyło et al., 2007; Lityńska et al., 2008; Zhao et al., 2008) and the presence of poly-Nacetyllactosamine residues which can provide additional antennae for the terminal capping by sialic acid (SA), resulting in the increase in tumour cell surface glycoproteins sialylation (Siddiqui et al., 2005; Laidler et al., 2006). In vertebrates, SA are typically linked to the inner sugar residue galactose (Gal) via $\propto 2,6$-or $\alpha 2,3$-linkage, or linked to galactosamine, N-acetylgalactosamine (GalNAC) or $\mathrm{N}$-acetylglucosamine (GlcNAc) via $\alpha 2,6$-linkage. Moreover, SA can also be linked to the $\mathrm{C} 8$ position of another $\mathrm{SA}$ residue to form a linear $\alpha 2,8$-homopolymer called polysialic acid (Wang, 2005a). To date, more than 20 different sialyltransferases, have been identified to be involved in biosynthesis of sialylated glycoproteins and glycolipids. They are Golgi membrane-bound glycosyltransferases which differ in their substrate specificity, tissue and cell distribution, induction profile and biochemical parameters (Harduin-Lepers et al., 2001; Varki \& Schauer 2009). The expression of the sialylated glycoconjugates at the cell surface is regulated mainly at the transcription level and a strong positive correlation between mRNA expression levels and sialyltransferases activity levels has been shown (Kitagawa \& Paulson, 1994; Harduin-Lepers et al., 2001; Taniguchi et al., 2003). Additionally, expression of each sialyltransferase is strictly

e-mail: malgorzata.przybylo@uj.edu.pl

Abbreviations: ECM, extracellular matrix; FN, fibronectin; Gal, galactose; MAA (MALII), Maackia amurensis lectin; RGP, radial growth phase; SA, sialic acids; SNA, Sambucus nigra lectin; VGP, vertical growth phase 
regulated in a development and cell-type specific manner (Kitagawa \& Paulson, 1994; Harduin-Lepers et al., 2001). The level of sialyltransferase expression is also dramatically changed during cancer transformation (Videira et al., 2009; Dall'Olio et al., 2000; Dall'Olio et al., 2004; Xu et al., 2003), and this is correlated with overexpression of tumour-associated sialylated structures, such as sialogangliosides fucosyl-GM1a, GM2, GM3, GD2 and GD3, sialyl-Tn, sialyl-T, sialyl-Le and sialyl-Lex ${ }^{\mathrm{x}}, \alpha 2,8$-linked polysialic acids and mucins at the surface of cancer cells (Wang, 2005a). The overexpression of these tumourassociated carbohydrate antigens has been reported for several epithelial cancers i.e. gastric (Pinho et al., 2007), pancreatic (Peracaula et al., 2005), colorectal (Szajda et al., 2008), ovarian (Wang et al., 2005b), bladder (Ohyama, 2008) and breast (Nakagoe et al., 2002; Julien et al., 2006).

The biosynthesis of sialylated molecules may act as a coding system, since they are able to interact with high specificity and selectivity with carbohydrate-binding proteins including lectins, antibodies, receptors and enzymes (Thomas, 1996). These molecules are also involved in cell communication such as cell-cell and cell-matrix interactions and molecular recognition during tumour development and progression (Varki \& Varki, 2007). Tumour cells tend to produce increased levels of glycoconjugates containing sialic acid that imparts a negative charge to the glycan chain (Schauer, 2009; Zhang et al., 2009), increase resistance to apoptosis (Büll et al., 2014a) and modulate the function of different immune cell subsets (Büll et al., 2014b) and the positive correlation between the cell surface sialylation and metastatic ability of various cell lines has been demonstrated (Dimitroff et al., 1999; Seales et al., 2005; Bartik et al., 2008; Christie et al., 2008, Wang et al., 2009). Enhanced sialic acid expression may alter tumour cell-cell interactions, promoting cell detachment from a site of origin. Because sialylated glycoconjugates regulate adhesion and promote motility, they may also be important for the colonization and metastatic potential of cancer cells (Julien et al., 2006), which correlates with a poor prognosis for patients ( $\mathrm{Pa}-$ tani et al., 2008; Shah et al., 2008).

Although a number of studies have shown altered sialylation profiles in various cancers, there is a dearth of reports on evaluation of sialic acid $\alpha 2,6-$ and $\alpha 2,3$-linkage role in human melanoma. Therefore, the purpose of the present study was to characterize sialylation pattern of four cell lines representing different steps of melanoma progression (i.e. WM1552C, WM115, IGR-39 and WM266-4 cells), and evaluate the impact of their sialylation status on these melanoma cell behaviour. Cell adhesion to fibronectin (FN) and cell migration (wound healing) on FN were selected as the studied cell behaviour parameters.

\section{MATERIAL AND METHODS}

Materials. Mouse monoclonal anti- $\alpha_{5}$ integrin antibody (clone SAM-1), mouse monoclonal anti- $\beta_{1}$ integrin antibody (clone B3B11), rabbit polyclonal antiserum against $\alpha_{5}$ integrin subunits and Immobilon $\mathrm{P}$ membrane, were purchased from MerckMillipore (Darmstadt, Germany). Mouse $\operatorname{IgG}_{1}-$ negative control and rabbit polyclonal anti-mouse $\left.\mathrm{F}(\mathrm{ab})^{\prime}\right) 2$ FITC-conjugated antibody were from DAKO (Denmark). Bovine serum albumin (BSA), trypsin/EDTA solution, penicillin/streptomycin solution, Streptavidin-agarose, Cell Dissociation Solution, goat anti-mouse AP-conjugated antibody, ExtrAvidin-
FITC, Maackia amurensis lectin (MAA), high molecular mass standards and protease inhibitor cocktail were obtained from Sigma Aldrich Chemical Co. (St. Louis, MO, USA). Phosphate buffered saline (PBS), RPMI 1640 medium with Glutamax-I (RPMIG) and foetal calf serum were from Life Technologies GibcoBRL ${ }^{\mathrm{TM}}$ (Paisley, UK). Biotinylated Maackia amurensis lectin (MAL-II), biotinylated Sambucus nigra lectin (SNA) as well as agarose bound SNA and agarose bound Streptavidine were from Vector Laboratories U.K. All remaining chemicals were of analytical grade, commercially available.

Cell lines and culture conditions. Four human melanoma cell lines derived from human melanoma lesion were used in this study: primary non-metastatic WM1552C cell line, which has a RGP-like phenotype (Hsu et al., 1998); non-metastatic/locally invading with metastatic potential WM115 cell line, which has a RGP/ VGP-like phenotype (Westermark et al., 1986); locally invading with metastatic potential IGR-39 cell line, which has a VGP-like phenotype (Aubert et al., 1980); and WM266-4 cell line, which is a metastatic cell line obtained from lymph node metastasis (Westermark et al., 1986). These cells were maintained as monolayer cultures in RPMI 1640 medium with Glutamax-I supplemented with $10 \%$ foetal calf serum and antibiotics (100 units/ $\mathrm{ml}$ of penicillin and $100 \mu \mathrm{g} / \mathrm{ml}$ of streptomycin) in $5 \%$ $\mathrm{CO}_{2}$-enriched atmosphere at $37^{\circ} \mathrm{C}$ in a humidified incubator. After reaching confluence, the cells were harvested for experiments adequately. All cell cultures were assayed for mycoplasma with standard tests.

Flow cytometric analysis. Expression of human integrin subunits was assessed by flow cytometry as previously described (Laidler et al., 2000). Briefly, cells $\left(1 \times 10^{5}\right)$ were incubated for $45 \mathrm{~min}$ on ice with antibodies against $\alpha_{5}$ integrin $(50 \mu \mathrm{l} / \mathrm{ml})$, or normal mouse $\operatorname{IgG}_{1}(50 \mu \mathrm{l} / \mathrm{ml})$ as a negative control. Next, cells were washed in PBS and incubated with $50 \mu \mathrm{l} / \mathrm{ml}$ fluorescein isothiocyanate (FITC)-conjugated anti-mouse $\operatorname{IgG}(\mathrm{Fab}) 2$ fragments for $45 \mathrm{~min}$ on ice. SNA- and MAA-binding to cells was performed according to the method of (Przybyło et al., $2008)$ with minor modification. Briefly, cells $\left(1 \times 10^{5}\right)$ were incubated with biotinylated SNA, an $\alpha 2,6$-linked sialic acids detecting lectin $(25 \mu \mathrm{g} / \mathrm{ml})$ or biotinylated MAL-II, an $\alpha 2,3$-linked sialic acids detecting lectin $(25 \mu \mathrm{g} / \mathrm{ml})$ in PBS containing $2 \% \mathrm{BSA}$, for $45 \mathrm{~min}$ on ice, followed by incubation with FITC-extravidin $(50 \mu \mathrm{l} / \mathrm{ml})$ under the same conditions. The assessment for fluorescence was done in a FACSCalibur flow cytometer (BD Biosciences, San Diego, CA) and a total of $10^{4}$ cells were analysed for each immunofluorescence profile.

Expression of sialyltransferases. RNA isolation, cDNA synthesis and PCR amplification of the samples was performed as previously described (Laidler et al., 2006) with minor modifications. Forward (F) and reverse (R) oligonucleotide primer sequences for sialyltransferase genes (Tanaka et al., 2000; Seales et al., 2003), lengths of the amplification products and annealing temperature are given in Table 1 . The reaction products, obtained after 30 cycles (1 min denaturing in $94^{\circ} \mathrm{C}, 1 \mathrm{~min}$ of annealing and 2 min of extension), were electrophoresed on $2 \%$ agarose containing ethidium bromide. The amplification of the GAPDH mRNA was used as a housekeeping gene. Glycosyltransferase mRNA analysis of each sample was determined in at least two independent experiments.

Cell adhesion assay. Cell adhesion assays were performed as previously described (Laidler et al., 2006) on a 96-well plate pre-coated with human FN (BD Biosciences). Before the assay cells were starved in 
Table 1. Forward (F) and reverse (R) oligonucleotide primer sequences for sialyltransferase genes, their annealing temperature and length of their products.

\begin{tabular}{|c|c|c|c|}
\hline Enzyme (acronym) & Oligonucleotide primers & $\begin{array}{c}\text { Annealing temperature } \\
{\left[{ }^{\circ} \mathrm{C}\right]}\end{array}$ & $\begin{array}{l}\text { Product length } \\
\text { [bp] }\end{array}$ \\
\hline $\begin{array}{l}\text { Alpha-2,3-silalyltransferase } 3 \\
\text { (ST3Gal-III, SIAT3) }\end{array}$ & $\begin{array}{l}\mathrm{F}: 5^{\prime}-A A C A A G T C T C T G G G G T C A C G-3 ' \\
\text { R:5'-TGAGGATTCGAATCTCAGGG-3' }\end{array}$ & 59.8 & 307 \\
\hline $\begin{array}{l}\text { Alpha-2,3-silalyltransferase } 4 \\
\text { (ST3Gal-IV, SIAT4C) }\end{array}$ & $\begin{array}{l}\mathrm{F}: 5^{\prime}-C T T C T T C A T G G A G A T T G C A G C-3^{\prime} \\
\text { R:5'-CTACAGCTCTTGCCCAGGTC-3' }\end{array}$ & 59.0 & 320 \\
\hline $\begin{array}{l}\text { Beta-galactoside alpha-2,6-sialyltransferase } 1 \\
\text { (ST6Gal1, SIAT1) }\end{array}$ & 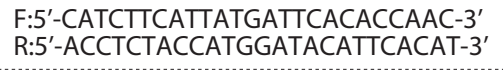 & 57.0 & 473 \\
\hline $\begin{array}{l}\text { glyceraldehyde-3-phosphate dehydrogenase } \\
\text { (GAPDH) }\end{array}$ & $\begin{array}{l}\text { F:5-CCACCCATGGCAAATTCCATGGCA-3' } \\
\text { R:5-TCTAGACGGCAGGTCAGGTCCACC-3 }\end{array}$ & 59.0 & 596 \\
\hline
\end{tabular}

serum-free medium for $60 \mathrm{~min}$, detached with Cell Dissociation Solution (Sigma Aldrich), washed and re-suspended with serum-free medium. The plate was washed with PBS and non-specific binding sites were blocked by incubation with $1 \% \mathrm{BSA}$ for $1 \mathrm{~h}$ at $37^{\circ} \mathrm{C}$. Cells $\left(5 \times 10^{4}\right)$ were added to the pre-treated wells and left for $1 \mathrm{~h}$ in $\mathrm{CO}_{2}$ incubator. Afterwards, wells were washed three times with PBS and adherent cells were fixed with $96 \%$ ethanol followed by triple wash with PBS and staining with $0.1 \%$ crystal violet water solution. Finally, cells were washed with tap water, airdried and treated with $0.5 \%$ Triton X-100 overnight. Absorbance was measured at $600 \mathrm{~nm}$. Non-specific cell adhesion was measured on BSA-coated wells and the estimation of the reference value for $100 \%$ attachment was performed on cells in wells coated with poly-L-lysine $(0.5 \mathrm{mg} / \mathrm{ml})$. In some experiment cells were pre-incubated for $1 \mathrm{~h}$ with SNA or MAA (both at a concentration of $25 \mu \mathrm{g} / \mathrm{ml}$ ). The applied dose of SNA or MAA had no effect on the viability or growth rate of the tested cells as demonstrated by trypan blue exclusion and 3[4,5-dimethyldiazol-2-yl]-2,5-diphenyltetrazolium bromide (MT'T) tests (data not shown). Changes in adhesion rate after lectin-treatment were calculated by comparing adhesion of untreated (set to $100 \%$ adhesion) and treated cells.

Wound healing assay. Wound healing assay was made according to (Przybyło et al., 2008) in a 6-well plate pre-coated with human FN (BD). In some experiments, wound healing in culture medium containing $25 \mu \mathrm{g} / \mathrm{ml}$ of SNA or $25 \mu \mathrm{g} / \mathrm{ml}$ of MAA was examined. Migration of cells into wounded area was observed in an inverted microscope and photographed. The average extent of wound closure was quantified by multiple measurements of the width of the wound space for each of these cases. Values are expressed as mean \pm standard deviation of three separate experiments.

Cell lysate preparation. After reaching confluence cells were washed, harvested and pelleted by centrifugation. Then cells were homogenised on ice by sonification (Bandelin Electronic) in $50 \mathrm{mM}$ Tris/ $\mathrm{HCl}, \mathrm{pH} 7.5$, containing $150 \mathrm{mM} \mathrm{NaCl}, 1 \mathrm{mM} \mathrm{MgCl}, 1 \mathrm{mM} \mathrm{MnCl}_{2}$ and proteases inhibitor cocktail, followed by extraction for $1 \mathrm{~h}$ on ice in the same buffer containing additionally $1 \%$ Triton X-100 and $0.3 \%$ protamine sulphate. Finally cell extracts were cleared by centrifugation at $18000 \times g$ for $1 \mathrm{~h}$. Protein concentration in the supernatants was determined (Peterson, 1977).

Precipitation of proteins bearing sialylated N-oligosaccharides. The precipitation was conducted as described previously by Pocheć and coworkers (2015) with minor modification. Three hundred micrograms of total protein from each cell lysate were incubated overnight at $4^{\circ} \mathrm{C}$ on an orbital rotator with SNA-agarose $(16 \mu \mathrm{l})$ or biotinylated MAA $(3.4 \mu \mathrm{l})$ in precipitation buffer $(10$ mM HEPES, $0.15 \mathrm{M} \mathrm{NaCl}, \mathrm{pH}$ 7.5). Additionally, $34 \mu \mathrm{l}$ of Streptavidin-agarose was added into a sample containing MAA $2 \mathrm{~h}$ before the end of incubation. Afterwards, SNA-glycoprotein or MAA-glycoprotein complexes were washed and the glycoproteins were released by boiling at $100^{\circ} \mathrm{C}$ for $10 \mathrm{~min}$ in LSB in the absence of reductant, and supernatants were collected.

SDS-PAGE and immunodetection of integrin subunits. Cell lysates and the samples after precipitation with lectins were separated by $8 \%$ SDS-PAGE under non-reducing conditions transferred onto PVDF membranes and tested with the use of specific antibodies against $\alpha_{5}$ and $\beta_{1}$ integrin subunits (1:2000 working dilution for $\alpha_{5}$ subunit, and 1:2000 working dilution for $\beta_{1}$ subunit). The secondary, AP-conjugated sheep anti-rabbit $\operatorname{IgG}$ (for $\alpha_{5}$ integrin subunits, 1:250 working dilution,) or goat anti-mouse $\operatorname{IgG}$ (for $\beta_{1}$ integrin subunit, 1:500 working dilution) were used. Colorimetric visualisation of immunoreactive proteins was achieved with the use BCIP and NBT substrates for AP (Roche).

Statistics. The significance of the differences between mean values was computed using Duncan's multiple range test and $P$-values lower than 0.05 were considered significant.

\section{RESULTS}

\section{Increased a2,3-sialylation is associated with more aggressive phenotype in melanoma}

In the first part of this study we used flow cytometry to compare WM1552C, WM115, IGR-39 and WM266-4 cells in terms of their cell surface sialylation applying specific lectins: Maackia amurensis (MAA) and Sambucus nigra (SNA) that detect sialic acids differently linked to Gal/GalNAc residue i.e. by $\alpha 2,3-$ or $\alpha 2,6-$ linkage, respectively. Although the examined cells had very similar, high expression of MAA-positive cells (Fig. 1A, B), in WM2664-4 cells the relative fluorescence intensity of MAA staining was at least three times greater than that of other cell lines (Fig. 1C). In turn, staining of the cells with SNA revealed that three cell lines studied (WM1552C, WM115 and WM2664) expressed significantly higher amount of $\alpha 2,6$-linked sialic acids on the cell surface than IGR-39 cells, as reflected in the percentage of positive cells (Fig. 1A, B) and the relative fluorescence intensity of SNA staining (Fig. 1C). Nevertheless, the reduced SNA-binding in IGR-39 cells did not result from differences in sialyltransferase expression at the mRNA level as revealed by semi-quantitative RT-PCR (Fig. 2). 

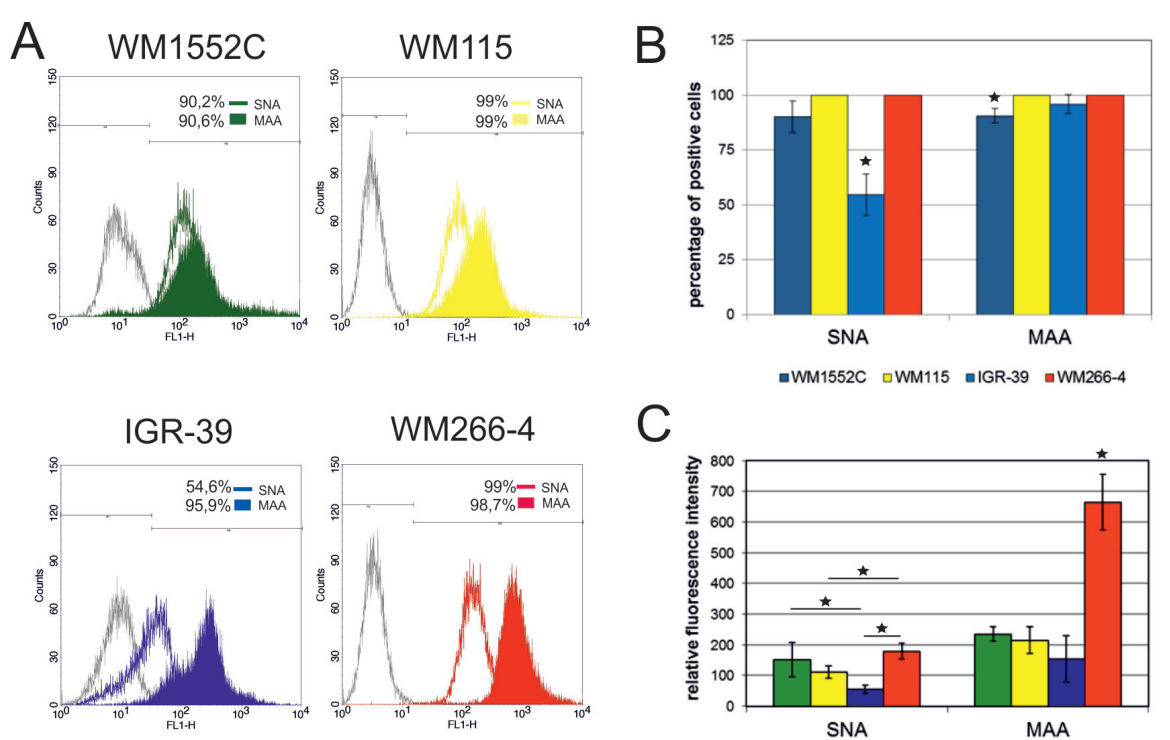

C

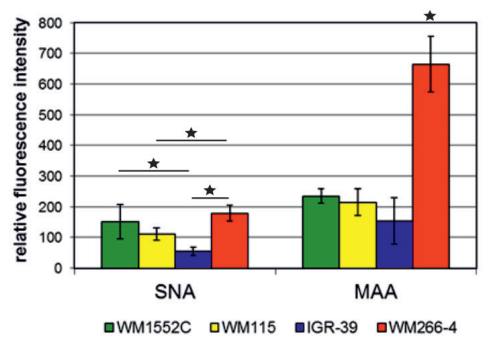

Figure 1. Flow cytometric analysis of SNA and MAA positive oligosaccharides presented on melanoma cells.

(A) Panel shows the histograms for SNA and MAA positive cell lines (coloured line for SNA and coloured areas for MAA. Open histograms represent background fluorescence. (B) Diagram shows the percentage of SNA and MAA positive melanoma cells. (C) Diagram shows the relative fluorescence intensity for each cell line obtained in flow cytometric analysis. All values are presented as mean \pm standard deviation of three independent experiments. Asterisks indicate $p \leq 0.05$. WM1552C - primary non-metastatic melanoma WM1552C cells; WM115 - non-metastatic/locally invading with metastatic potential WM115 melanoma cells; IGR-39 - locally invading with metastatic potential IGR-39 cells; WM266-4 - metastatic melanoma WM266-4 cells.

\section{Adhesion and migration properties of melanoma cells}

The ability of cancer cells to adhere to extracellular matrix proteins and subsequently to migrate through them is an important factor in the metastatic cascade (Menon \& Beningo, 2011; Polacheck et al., 2013). For this reason, we evaluated adhesion and migration (by wound healing) abilities of the studied cells in terms of

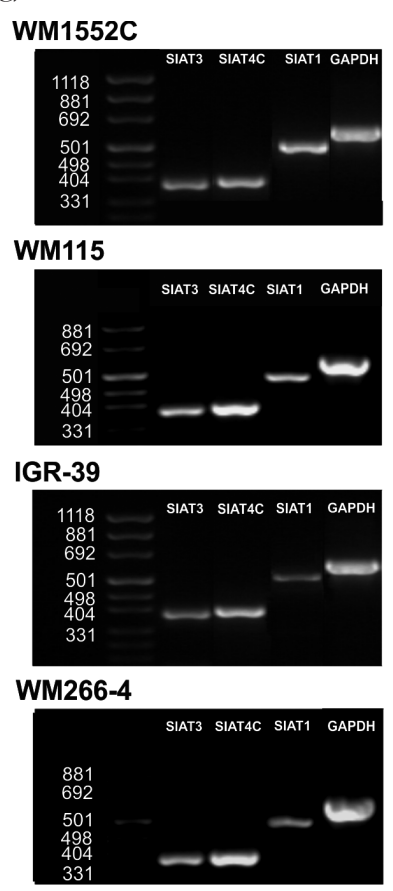

Figure 2. RT-PCR analysis of sialylotransferases gene expression. The expression level of target genes was normalized to GAPDH expression. their interaction with $\mathrm{FN}$ and estimated the impact of sialic acids on these interactions. Briefly, to investigate whether sialic acid content affects the adhesive and migration properties of the tested cells, MAA and SNA were added during the execution of the adhesion and migration assays. As shown at Fig. 3A, the adhesion efficiency of WM1552C, WM115 cells (representing RGP and RGP/VGP, respectively) was significantly lower than that of IGR-39 and WM266-4 cells (representing VGP and metastatic melanoma, respectively). Performing adhesion assays in the presence of SNA reduced the levels of adhesion only in IGR-39 and WM2664 cell lines, by $75 \%$ and 100\%, respectively (Fig. 3B). In contrast, the presence of MAA during adhesion assay caused a dramatic decline in the number of adhering cells in all examined cell lines within the range from $87 \%$ to $98 \%$ (Fig. 3B). These results indicated that $\alpha 2,3$-linked sialic acids could be a more important factor increasing melanoma cell adhesion than $\alpha 2,6$-linked sialic acids.

As far as migration abilities of the studied melanoma cells are concerned, it was found that metastatic melanoma cells (WM266-4) repaired scratch wounds at least twice as fast as primary melanoma cells (Fig. 4A, B). As presented in Fig. 4C, addition of SNA resulted in the decrease of melanoma cell migration rate into scratch wounds on FN-coated wells only for WM266-4 cells, but the effect was relatively weak (by 20\%). It was also proved as documented in Fig. 4C that the presence of MAA during wound healing assays blocked melanoma cell motility with different degree. The observed effect was more noticeable in two primary melanoma cells (WM1552C, and IGR-39 cells by $70 \%$ and 50\%, respectively) than in two other cell lines (WM115 and WM2664 both by $33 \%$ ). It showed that $\alpha 2,3$-linked sialic acids present on the cell surface of melanoma cells could increase their migration potential.

\section{Integrin $\alpha_{5} \beta_{1}$ as a carrier of sialic acids in melanoma}

Afterwards, we precipitated clarified lysates of WM1552C, WM115, IGR-39 and WM266-4 cells with MAA and SNA. The glycoproteins recovered after precipitation were separated by SDS-PAGE under non-reducing conditions, blotted onto PVDF membrane and probed with antibodies against $\alpha_{5}$ and $\beta_{1}$ integrin subunits. The presence of $\alpha 2,6$-linked SA was confirmed on both chains in all cell lines (Fig. 5). Similarly, $\alpha 2,3$-linked SAs were detected generally on $\beta_{1}$ integrin subunit in all melanoma cell lines, but not on $\alpha_{5}$ integrin subunit in IGR-39 cells (Fig. 5). The flow cytometric data summarized in Fig. 6 (A, B), showed that the cell surface expression of the main $\mathrm{FN}$ receptor, i.e. $\alpha_{5} \beta_{1}$ integrin, 
A

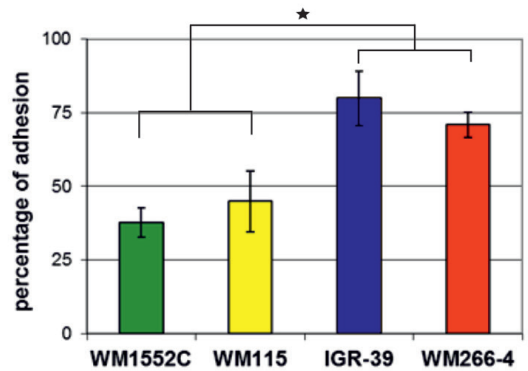

B

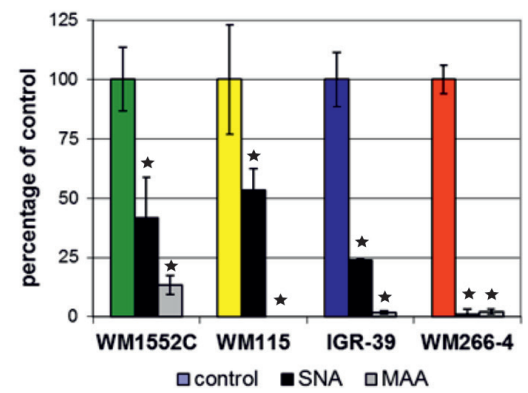

Figure 3. Studies on human non-metastatic (WM1552C, WM115, IGR-39) and metastatic (WM266-4) melanoma cells adhesion to FN.

(A) Adhesion properties of melanoma cells. All data are given as percentage of adhesion relative to adhesion on poly-L-lysine (taken as $100 \%$ ). Cell adhesion to BSA-coated wells served as a negative control. (B) Effect of SNA and MAA on the adhesion of melanoma cells to FN. The extent of cell adhesion in the presence of the lectins is presented relatively to cell adhesion in their absence that was considered as $100 \%$. Each result is the mean of three independent experiments. Error bars indicate standard deviations. Asterisks indicate $p \leq 0.05$.

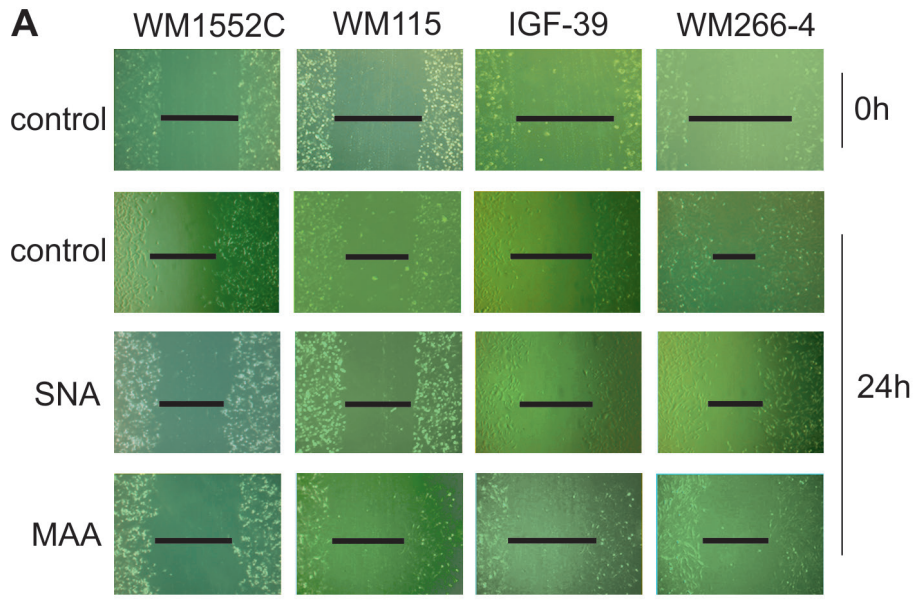

B

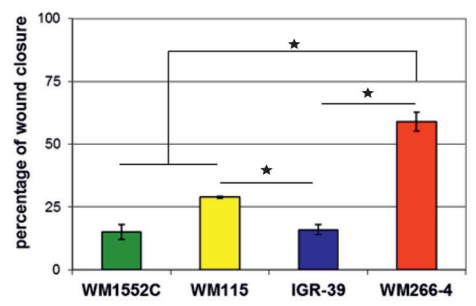

C

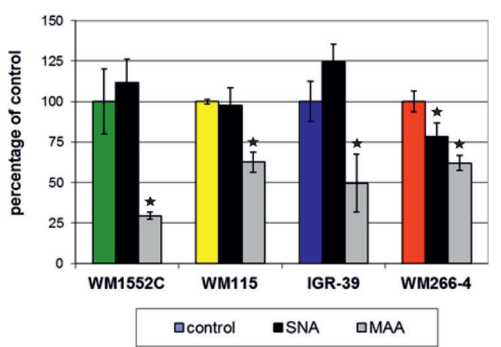

varied between the tested cell lines. In general, high expression level of this receptor was found in IGR-39 and WM266-4 cells $(79 \%$ and $75 \%$, respectively), but relatively low in WM1552C and WM155 cells $(9 \%$ and $25 \%$, respectively). These results also showed that the level of $\alpha_{5} \beta_{1}$ integrin expression on melanoma cells was associated (increased) with the progression of disease, and probably correlated with the strength of melanoma cell adhesion to FN-coated surfaces.

\section{DISCUSSION}

Cancer-related changes in oligosaccharide structures are well documented in diverse carcinomas, including melanoma (Lityńska et al., 2001; Przybyło et al., 2007; Lityńska et al., 2008; Przybyło \& Lityńska 2011), and they are often correlated with tumour progression, metastatic spread, reconstruction of the vascular system, and poor prognosis. Elevated expression of sialylated glycoprotein and glycolipids has been proved to closely correlate with tumour aggressiveness, tumour cell invasiveness and capacity to metastasize, and therefore correlates with a poor prognosis (Shah et al., 2008).

In the present study we demonstrated by flow cytometry that melanoma progression is associated with significant increase in $\alpha 2,3$-linked SA on the surface of metastatic melanoma cells (WM266-4) compared to primary melanoma cells of a different growth phase (WM1552C, WM115, and IGR-39). The addition of $\alpha 2,3$-lined SA can be catalysed by two Galß1-3GalNAc $\alpha 2,3$-sialyltransferases (ST3Gal I and ST3Gal II), Galß14GlcNAc $\alpha 2,3$-sialyltransferases (ST3Gal IV) and Gal $\beta 1-$ 3(4)GlcNAc $\alpha 2,3$-sialyltransferases (ST3Gal III) (Chang et al., 1995; Harduin-Lepers et al., 2001; Varki \& Schauer 2009). ST3GAL I plays a role in formation of sialyl-T antigen, whereas ST3GAL IV in sialyl-Le ${ }^{\mathrm{x}}$ epitope formation. Nevertheless, the differences in sialic acid con-
Oh

Figure 4. Analysis of migration of nonmetastatic (WM1552C, WM115, IGR-39) and metastatic (WM266-4) melanoma cells on FN by in vitro scratch assay.

The wound was scratched with a plastic pipette tip through a confluent monolayer of cells maintained on FN-coated surfaces. The scratch-wounded cultures were allowed to heal for $24 \mathrm{~h}$ and in some experiments they were additionally cultured in the presence of SNA or MAA. (A) Photographs of wounded area in time $0 \mathrm{~h}$ and at 24 h. (B) Diagram shows migration properties of melanoma cells. (C) Effect of treatment with SNA and MAA on repair of scratch wounds in monolayers of melanoma cells. Changes in migration rate after lectin treatment were calculated by comparing the migration of untreated (taken as $100 \%)$ and treated cells. Values are means \pm standard deviation of three separate experiments. Asterisks indicate $P \leq 0.05$. 

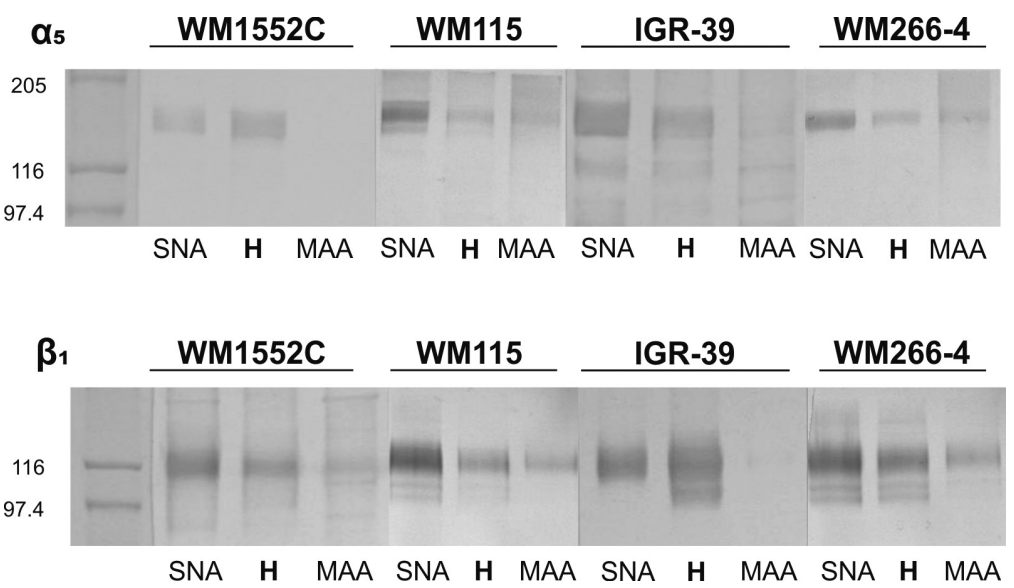

Figure 5. Immunodetection of $\alpha_{5}$ and $\beta_{1}$ integrin subunits in materials obtained after precipitation with SNA and MAA lectins.

Line $\mathrm{H}$ shows reaction for homogenate, and SNA or MAA lines represent the reaction in materials after precipitation.

tent observed by us, as detected by MAA lectin binding, seemed not to be reflected by their mRNA level as estimated by semi-quantitative RT-PCR. Interestingly, to date, several mechanisms are taken into account as a cause of tumour cell hypersialylation: overexpression and/or altered activity of sialyltransferases and sialidases, hypoxia, high level of androgens, metabolic changes in sialic acid biosynthesis in the tumour microenvironment, and differential expression of endogenous sialidases (Büll et al., 2014a; Vajaria et al., 2014). Therefore further detailed studies are needed to reveal molecular mechanisms responsible for hypersialylation in melanoma cells.

In line with our results mentioned above are reports showing the association of $\alpha 2,3$-linked SA expression with higher invasive and metastatic potential of gastric, colon, breast, skin and lung cancer cells (Wang et al., 2009; Gomes et al., 2013; Cui et al., 2011; Chen et al., 2011; Shah et al., 2008; Chovanec et al., 2004). Additionally, increased $\alpha 2,3$ sialylation was observed in prostate cancer samples, malignant brain tumours and ovarian
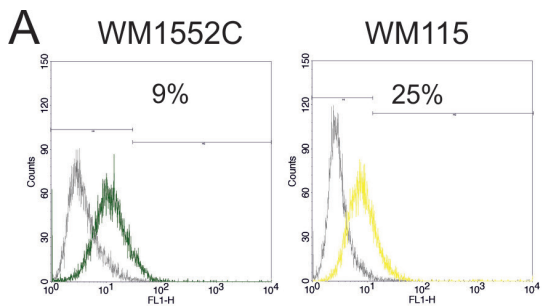

B
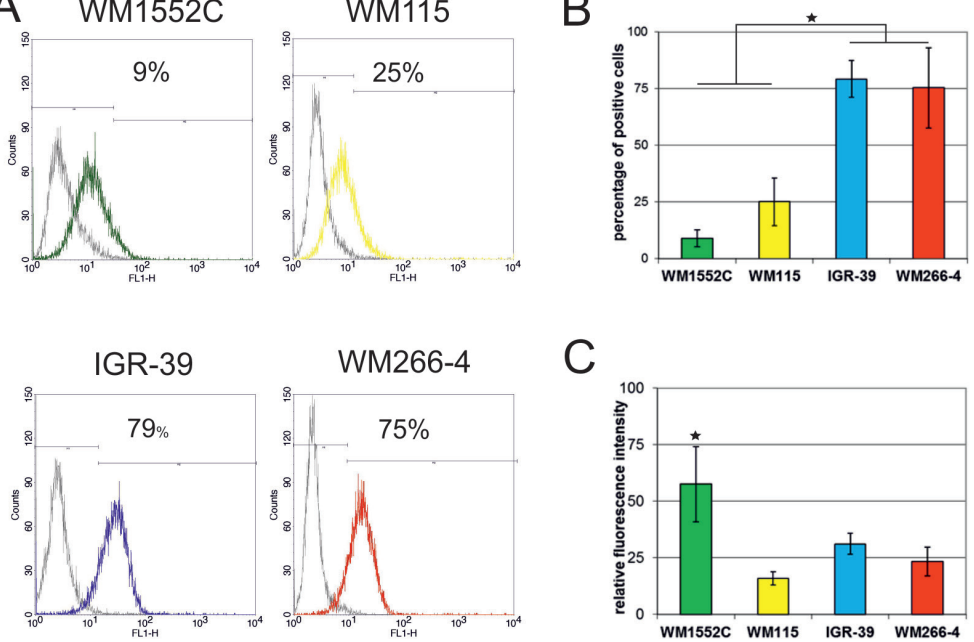

$\mathrm{C}$

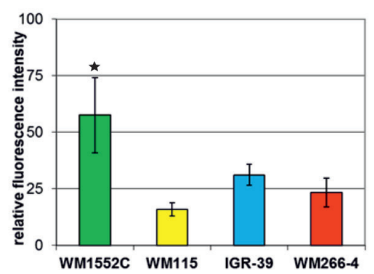

Figure 6. Expression of integrin $\alpha_{5} \beta_{1}$ in WM1552C, WM115, IGR-39 and WM266-4 melanoma cell lines analysed.

(A) Panel shows the histograms for $a_{5} \beta_{1}$ positive cell lines (coloured line). Open histograms represent background fluorescence. (B) Diagram shows the percentage melanoma cells expressing $a_{5} \beta_{1}$ integrin. (C) Diagram shows the relative fluorescence intensity for each cell line obtained in flow cytometric analysis. All values are presented as mean \pm standard deviation of three independent experiments. Asterisks indicate $\mathrm{p} \leq 0.05$. serous carcinoma (Saldova et al., 2011; Yamamoto et al., 1997; Wang et al., 2005b). Interestingly, in breast cancer patients the high level of $\alpha 2,3$-linked SA was closely associated with lymph node metastasis and the depth of invasion (Cui et al., 2011). Moreover, $\alpha 2,3-$ linked SAs are involved in the synthesis of sialyl-Lewis $\mathrm{x}$ antigens (SLex), which are known to facilitate tumour cell dissemination via mediating interaction between tumour and endothelial cells (Padler-Karavani, 2014). However, there are substantial amounts of data showing as well that in the majority of carcinomas studied so far (breast, bladder, prostate, stomach, pancreas, colon and cervix, acute myeloid leukemia, chloricarcinomas, and in some brain tumours), elevated expression of $\alpha 2,6$-linked SA actually plays an important role in tumour progression (Hedlund et al., 2008; Schultz et al., 2012; Lu \& Gu, 2015). In our experimental model, a very large percentage of all tested melanoma cells was a carrier of cell surface $\alpha 2,6-$ ialycoconjugates, but IGR-39 cells, which represent a VGP-like phenotype, were found to possess a lower amount thereof, as shown by relative fluorescence value of SNA binding. The molecular mechanisms responsible for the observed phenomena are unravelled. However, been demonstrated that upregulation of particular sialyltransferases and subsequent altered expression of some sialylated glycoconjugates took place during epithesite for cancer cells to invade surrounding tissue and mestasize, (Maupin et al., 2010; Sakuma et al., 2012). Induction of EMT in colon cancer cells by epidermal growth factor leaded to increased expression of ST3Gal I, III $\beta$-induces ETM upregulation of ST3Gal II, ST6GalNAc IV (one of GalNAc $\alpha 2,6$-sialyltransferase) and ST8Sia IV (one of $\alpha 2,8$-sialyltransferase) was observed. The question is whether decreased level of $\alpha 2,6-$ linked sialylated glycoconjugates in IGR39 cells could be a result of elevated expression of ST3Gal. To date, there is no information on possible competition between $\alpha 3$ - and $\alpha 6$-sialyltranfserases for the common substrates. Moreover, although loss of expression or overexpression of certain sialystransferases is frequently observed in majority of cancers, there is no detailed information on altered expression of these enzymes in melanoma ( $\mathrm{Lu} \& \mathrm{Gu}, 2015)$.

Aberrantly high sialic acid level is known to play a pivotal role in multiple aspects of tumour growth and behaviour, among others it facilitates tumour cell detachment and increases migration and tissue invasion abilities (Ohtsubo \& Marth, 2006; Dall'Olio et al., 2014; Büll et al., 2014a; Lu \& Gu, 2015). Here we compared melanoma cells derived from different growth phases with respect to adhesion and migration. The cells which represented RGP- and RGP/VGP-like phenotype, i.e. WM1552C and WM115 cells, were characterized by a two-fold 
lower adhesiveness than the cells that represented VGPand metastatic phenotype, i.e. IGR-39 and WM266-4 cells. Moreover, the motility of metastatic cells was twice as high than for other cells tested. Previous studies have demonstrated that the elevated level of cell surface $\alpha 2,6-$ linked SA correlated with higher cell adhesion to following ECM components: FN, laminin and collagen, while higher levels of $\alpha 2,3$-linked SA promoted migration and metastasis (Chang et al., 2006; Perez-Garay et al., 2010; Cui et al., 2011; Bassaganas et al., 2014). Here we demonstrated that pre-treatment of melanoma cells with specific lectins (MAA and SNA) impaired cell binding to $\mathrm{FN}$ and their migratory capacity in vitro, but the effect of $\alpha 2,3$-linked SA was much more important than $\alpha 2,6$-linked SA. In these studies, increases in $\alpha 2,3$-linked SA levels have been correlated with enhanced cell adhesion and motility, thus implying that $\alpha 2,3$-linked SA in human melanoma cells could play a pivotal role in cell adhesion and migration, through which they are involved in the metastatic process. Other studies have also shown that inhibition of $\alpha 2,3$-linked SA decreased the migratory ability of B16F10 cells and reduce cell adhesion to ECM proteins (Chang et al., 2006). These findings are in a striking contrast to the results obtained by Reddy \& Kalraiya (2006) in the studies on B16F10 mouse melanoma cells, in which $\alpha 2,6$-linked SAs were responsible for higher motility and adherence to the substrates.

The integrin family represents a particularly important adhesion receptors that mediate cell-cell and cell-ECM interactions. Integrin $\alpha_{5} \beta_{1}$, which is a classical FN receptor, plays an essential role in cancer progression in several solid tumours and is regarded as a pertinent therapeutic target (Schaffner et al., 2013). Its overexpression is particularly demonstrated in the most aggressive tumour grades. In line with these observations are our results in which we showed a higher expression level of this receptor on IGR-39 and WM266-4 cells than on WM1552C and WM115 cells. We also observed the presence of $\alpha 2,3$-linked SA generally on $\beta_{1}$ integrin subunit on all melanoma cell lines, but not on $\alpha_{5}$ integrin subunit on WM1552C cells. $\alpha 2,6$-linked SA were commonly present in both subunits of $\alpha_{5} \beta_{1}$ integrin in all tested cell lines. Glycosylation status of integrins has been reported to affect their binding to ECM and cell motility (Janik et al., 2010b).

In conclusion, our results suggested that $\alpha 2,3-$ sialylation was associated with more aggressive phenotype in melanoma. The role of $\alpha 2,6$-linked sialic acids seems to be less significant in melanoma cell behaviour. This feature may be useful in seeking novel target for therapeutic approach and for the development of new strategies for cancer treatment.

\section{Acknowledgements}

This work was supported by a grant N N301 032134 from the Ministry of Science and Higher Education in Poland (MNiSW) and grant K/ZDS/004829 from the Jagiellonian University in Krakow, Poland.

\section{REFERENCES}

Aubert C, Rouge F, Galindo JR (1980) Tumorigenicity of human malignant melanocytes in nude mice in relation to their differentiation in vitro. J Natl Cancer Inst 64: 1029-1040.

Bartik P, Maglott A, Entlicher G, Vestweber D, Takeda K, Martin S Dontenwill M (2008) Detection of a hypersialylated $\beta 1$ integrin endogenously expressed in the human astrocytoma cell line A172. Int J Oncol 32: 1021-1031.

Bassaganas S, Perez-Garay M, Peracaula R (2014) Cell surface sialic acid modulates extracellular matrix adhesion and migration in pan- creatic adenocarcinoma cells. Pancreas 43: 109-117. doi: $10.1097 /$ MPA.0b013e31829d9090.

Bellis SL (2004) Variant glycosylation: an underappreciated regulatory mechanism for beta1 integrins. Biochim Biophys Acta 1663: 52-60.

Büll C, Stoel MA, den Brok MH, Adema GJ (2014a) Sialic acids sweeten a tumor's life. Cancer Res 74: 3199-3204. doi: 10.1158/0008-5472. CAN-14-0728.

Büll C, den Brok MH, Adema GJ (2014b) Sweet escape: Sialic acids in tumor immune evasion. Biochim Biophys Acta 1846: 238-246. doi: 10.1016/j.bbcan.2014.07.005.

Chang ML, Eddy RL, Shous TB, Lau JTY (1995) Three genes encode human $\beta$-galactoside $\alpha 2-3$ sialyltransferses. Structural analysis and chromosomal mapping. Glycobiology 5: 319-325.

Chang WW, Yu CY, Lin TW, Wang PH, Tsai YC (2006) Soyasaponin I decreases the expression of $\alpha 2,3$-linked sialic acid on the cell surface and supress the metastatic potential of B16F10 melanoma cells. Biochem Biophys Res Commun 341: 614-619.

Chen JY, Tang YA, Huang SM, Juan HF, Wu LW, Sun YC, Wang Sc, Wu KW, Balraj G, Chang TT, Li WS, Cheng HC, Wang YC (2011) A novel sialyltransferase inhibitor suppresses FAK/paxillin signalling and cancer angiogenesis and metastatic pathways. Cancer Res 71: 473-483. doi: 10.1158/0008-5472.CAN-10-1303.

Chovanec M, Plzak J, Betka J, Brabec J, Kodet R, Smetana K Jr (2004) Comparative analysis of $\alpha 2,3 / 2,6$-linked $\mathrm{N}$-acetyneuraminic acid and cytokeratin expression in head and neck squamous cell carcinoma. Oncol Rep 12: 297-301.

Christie DR, Shaikh FM, Lucas IV JA, Lucas III JA, Bellis SL (2008) ST6Gal-I expression in ovarian cancer cells promotes an invasive phenotype by altering integrin glycosylation and function. I Ovarian Res 1: 3. doi: 10.1186/1757-2215-1-3.

Couldrey C, Green JE (2000) Metastases: the glycan connection. Breast Cancer Res 2: 321-323.

Cui H, Lin Y, Yue L, Zhao X, Liu J (2011) Differential expression of the $\alpha 2,3$-sialic acid residues in breast cancer is associated with metastatic potential. Oncol Rep 25: 1365-1371. doi: 10.3892/or.2011.1192.

Dall'Olio F (2000) The sialyl- $\alpha 2,6$-lactosaminyl-structure: Biosynthesis and functional role. Glycoconj J 17: 669-676.

Dall'Olio F, Chiricolo M, D'Errico A, Gruppioni E, Altimari A, Fiorentino M, Grigioni WF (2004) Expression of $\beta$-galactoside $\alpha 2,6$ sialyltransferase and of $\alpha 2,6$-sialylated glycoconjugates in normal human liver, hepatocarcinoma, and cirrhosis. Glycobiology 14: 39-49.

Dall'Olio F, Malagolini N, Trinchera M, Chiricolo M (2014) Sialosignaling: sialyltransferasea as engines of self-fueling loops in cancer progression. Biochim Biophys Acta 1840: 2752-2764. doi: 10.1016/j. bbagen.2014.06.006.

Dimitroff CJ, Pera P, Dall'Olio F, Matta KL, Chandrasekaran EV, Lau JTY, Bernacki RJ (1999) Cell surface $\mathrm{N}$-acetylneuraminic acid $\alpha 2,3$ galactoside-dependent intercellular adhesion of human colon cancer cells. Biochem Biophys Res Comm 256: 631-636.

Gallagher WM, Bergin OE, Rafferty M, Kelly ZD, Nolan IM, Fox EJP, Culhane AC, McArdle L, Fraga MF, Hughes L, Currid CA, O’Mahony F, Byrne A, Murphy AA, Moss C, McDonnell S, Stallings RL, Plumb JA, Esteller M, Brown R, Dervan PA, Easty DJ (2005) Multiple markers for melanoma progression regulated by DNA methylation: insights from transcriptomic studies. Carcinogenesis 26: 1856-1867.

Gomes C, Osorio H, Pinto MT, Campos D, Oliveira MJ, Reis CA (2013) Expression of ST3GAL4 leads to SL(x) expression and induces c-Met activation and invasive phenotype in castric carcinoma cells. PLoS One 8: e66737. doi: 10.1371/journal.pone.0066737.

Gu J, Taniguchi N (2008) Potential of N-glycan in cell adhesion and migration as either a positive or negative regulator. Cell Adh Migr 2: $243-245$.

Guo HB, Liu F, Zhao JH, Chen HL (2000) Down-regulation of acetylglucosaminyltransferase $\mathrm{V}$ by tumorigenesis- or metastasis suppressor gene and its relation to metastatic potential of human hepatocarcinoma cells. I Cell Biochem 79: 370-385.

Guo HB, Lee I, Kamar M, Akiyama SK, Pierce M (2002) Aberrant $\mathrm{N}$-glycosylation of $\beta_{1}$ integrin causes reduced $\alpha_{5} \beta_{1}$ integrin clustering and stimulates cell migration. Cancer Res 62: 6837-6845.

Harduin-Lepers A, Vallejo-Ruiz V, Krzewinski-Recchi MA, Samyn-Petit B, Julien S, Delannoy P (2001) The human sialyltransferase family. Biochimie 83: 727-737.

Hedlund M, Ng E, Varki A, Varki NM (2008) $\alpha 2,6$-Linked sialic acids on N-glycans modulate carcinoma differentiation in vivo. Cancer Res 68: 388-394. doi: 10.1158/0008-5472.CAN-07-1340.

Hsu MY, Shih DT, Meier FE, Van Belle P, Hsu JY, Elder DE, Buck CA, Herlyn M (1998) Adenoviral gene transfer of beta3 integrin subunit induces conversion from radial to vertical growth phase in primary human melanoma. Am I Pathol 153: 1435-1442.

Janik ME, Przybyło M, Pocheć E, Pokrywka M, Lityńska A (2010a) Effect of $\alpha 3 \beta 1$ and $\alpha \mathrm{v} \beta 3$ integrin expression on interaction of melanoma cells with vitronectin. Acta Biochim Pol 57: 55-61.

Janik ME, Lityńska A, Vereecken P (2010b) Cell migration - the role of integrin glycosylation. Biochim Biophys Acta 1800: 545-555. doi: 10.1016/j.bbagen.2010.03.013. 
Janik ME, Lityńska A, Przybyło M (2014) Studies on primary uveal and cutaneous melanoma cell interaction with vitronectin. Cell $\mathrm{Mol}$ Int 38: 942-952. doi: 10.1002/cbin.10280.

Julien S, Adriaenssens E, Ottenberg K, Furlan A, Courtand G, Vercoutter-Edouart AS, Hanisch FG, Delannoy P, Le Bourhis X (2006) ST6GalNAc I expression in MDA-MB-231 breast cancer cells greatly modifies their O-glycosylation pattern and enhances their tumourigenicity. Glycobiol 16: 54-64.

Kitagawa H, Paulson JC (1994) Differential expression of five sialyltransferases. J Biol Chem 264: 10931-10934.

Laidler P, Gil D, Pituch-Noworolska A, Ciołczyk D, Książek D, Przybyło M, Lityńska A (2000) Expression of beta1-integrins and N-cadherin In bladder cancer and melanoma cell lines. Acta Biochim Pol 47: 1159-1170.

Laidler P, Lityńska A, Hoja-Łukowicz D, Łabędź M, Przybyło M, Ciołczyk-Wierzbicka D, Pocheć E, Trębacz E, Kremser E (2006) Characterization of glycosylation and adherent properties of melanoma cell lines. Cancer Immunol Immunother 55: 112-118.

Li G, Herlyn M (2000) Dynamics of intercellular communication during melanoma development. Mol Med Today 6: 163-169.

Lityńska A, Przybyło M, Pocheć E, Hoja-Łukowicz D, Ciołczyk D, Laidler P, Gil D (2001) Comparison of the lectin-binding pattern in different human melanoma cell lines. Melanoma Res 11: 205-212.

Lityńska A, Przybyło M, Hoja-Lukowicz D, Pocheć E, Kremser M, Ciołczyk-Wierzbicka D, Labadź M, Laidler P (2008) Protein Glycosylation as Marker of Melanoma Progression. Curr Cancer Ther Rev 4: $144-148$.

Lu J, Gu J (2015) Significance of $\beta$-galactoside $\alpha 2,6$ sialyltransferase 1 in cancers. Molecules 20: 7509-7527. doi: 10.3390/molecules20057509.

Maupin KA, Sinha A, Eugster E, Miller J, Ross J, Paulino V, Keshamouni VG, Tran N, Berens M, Webb C, Haab BB (2010) Glycogene expression alterations associated with pancreatic cancer epithelialmesenchymal transition in complementary model systems. PLoS One 5: e13002.

Menon S, Beningo KA (2011) Cancer cell invasion is enhanced by applied mechanical stimulation. PLoS One 6: e17277. doi: 10.1371/ journal.pone.0017277.

Nadanaka S, Sato C, Kitajima C, Katagiri K, Irie S, Yamagata T (2001) Occurrence of oligosialic acids on integrin $\alpha_{5}$ Subunit and their involvement in cell adhesion to fibronectin. $J$ Biol Chem 276: $33657-$ 33664.

Nakagoe T, Fukushima K, Itoyanagi N, Ikuta Y, Oka T, Nagayasu T, Ayabe H, Hara S, Ishikawa H, Minami H (2002) Expression of $\mathrm{ABH} /$ Lewis-related antigens as prognostic factors in patients with breast cancer. J Cancer Res Clin Oncol 128: 257-264.

Ochwat D, Hoja-Łukowicz D, Lityńska A (2004) N-glycoproteins bearing $\beta 1-6$ branched oligosaccharides from the A375 human melanoma cell line analysed by tandem mass spectrometry. Melanoma Res 14: 479-485.

Ohyama C (2008) Glycosylation in bladder cancer. Int J Clin Oncol 13: 308-313. doi: 10.1007/s10147-008-0809-8.

Ohtsubo K, Marth JD (2006) Glycosylation in cellular mechanisms of health and disease. Cell 126: 855-867.

Padler-Karavani V (2014) Aiming at the sweet side of cancer: aberrant glycosylation as possible target for personalized-medicine. Cancer Lett 352: 102-112. doi: 10.1016/j.canlet.2013.10.005.

Patani N, Jiang W, Mokbel K (2008) Prognostic utility of glycosyltransferase expression in breast cancer. Cancer Genomics Proteomics 5: 333-340.

Peracaula R, Tabarés G, López-Ferrer A, Brossmer R, de Bolós C, de Llorens R (2005) Role of sialyltransferases involved in the biosynthesis of Lewis antigens in human pancreatic tumour cells. Glycoconj J 22: 135-144.

Perez-Garay M, Artera B, Pages L, de Liorens R, de Bolos C, VidalVanaclocha F, Peracaula R (2010) $\alpha 2,3$-sialyltransferase ST3Gal III modulates pancreatic cancer cell motility and adhesion in vitro and enhances its metastatic potential in vivo. PLoS One 5: el12524. doi: 10.1371/journal.pone.0012524.

Peterson GL (1977) A simplification of the protein assay method of Lowry et al. which is more generally applicable. Annal Biochem 83: 346-356.

Pinho S, Marcos NT, Ferreira B, Carvalho AS, Oliveira MJ, Santos-Silva F, Harduin-Lepers A, Reis CA (2007) Biological significance of cancer-associated sialyl-Tn antigen: Modulation of malignant phenotype in gastric carcinoma cells. Cancer Lett 249: 157-170.

Pocheć E, Lityńska A, Amoresano A, Casbarra A (2003) Glycosylation propfile of integrin alpha 3 beta 1 changes with melanoma progression. Biochim Biophys Acta 1643: 113-123.

Pocheć E, Janik M, Hoja-Lukowicz D, Link-Lenczowski P, Przybyło M, Lityńska A (2013) Expression of integrins $\alpha 3 \beta 1$ and $\alpha 5 \beta 1$ and GlcNAc $\beta 1,6$ glycan branching influences metastatic melanoma cell migration on fibronectin. Eur J Cell Biol 92: 355-362. doi: 10.1016/j. ejcb.2013.10.007.

Pocheć E, Bubka M, Rydlewska M, Janik M, Pokrywka M, Lityńska A (2015) Aberrant glycosylation of $\mathrm{v} \beta 3$ integrin is associated with melanoma progression. Anticancer Res 35: 2093-2103.
Polacheck WJ, Zervantonakis IK, Kamm RD (2013) Tumor cell migration in complex microenvironments. Cell Mol Life Sci 70: 133513356. doi: 10.1007/s00018-012-1115-1.

Przybyło M, Martuszewska D, Pocheć E, Hoja-Lukowicz D, Lityńska A (2007) Identification of proteins bearing $\beta 1-6$ branched N-glycans in human melanoma cell lines from different progression stages by tandem mass spectrometry analysis. Biochim Biophys Acta 1770: 14271435.

Przybyło M, Pocheć E, Link-Lenczowski P, Lityńska A (2008) ß1-6 branching of cell surface glycoproteins may contribute to uveal melanoma progression by up-regulating cell motility. Mol Vis 14 : 625-636.

Przybyło M, Lityńska A (2011) Glycans in melanoma screening. Part 1. The role of $\beta 1,6$ branched N-linked oligosaccharides in melanoma. Biochem Soc Trans 39: 370-373. doi: 10.1042/BST0390370.

Reddy BV, Kalraiya RD (2006) Sialilated $\beta 1,6$ branched N-oligosaccharides modulate adhesion, chemotaxis and motility of melanoma cells: effect on invasion and spontaneous metastasis properties. Biochim Biophys Acta 1760: 1393-1402.

Ruiter DJ, van Muijen GNP (1998) Markers of melanocytic tumour progression. I Pathol 186: 340-342.

Sakuma K, Aoki M, Kannagi R (2012) Transcription factors c-Myc and CDX2 mediate E-selectin ligand expression in colon cancer cells undergoing EGF/bFGF-induced epithelial-mesenchymal transition. Proc Natl Acad Sci USA 109: 7776-7781. doi: 10.1073/ pnas.1111135109.

Saldova R, Fan Y, Fitzpatrick JM, Watson RW, Rudd PM (2011) Core fucosylation and $\alpha 2-3$ sialylation in serum $\mathrm{N}$-glycome is significantly increased in prostate cancer comparing to benign prostate hyperplasia. Glycobiology 21: 195-205. doi: 10.1093/glycob/cwq147.

Schaffner F, Ray AM, Dontenwill M (2013) Integrin $\alpha 5 \beta 1$, the fibronectin receptor, as a pertinent therapeutic target in solid tumors. Cancer 5: 27-47. doi: 10.3390/cancers5010027.

Schauer R (2009) Sialic acids as regulators of molecular and cellular interactions. Curr Opin Struct Biol 19: 507-514. doi: 10.1016/j. sbi.2009.06.003.

Schultz MJ, Swindall AF, Bellis SL (2012) Regulation of the metastatic cell phenotype by sialylated glycans. Cancer Metastasis Rev 31: 501518. doi: $10.1007 / \mathrm{s} 10555-012-9359-7$.

Seales EC, Jurado GA, Singhal A, Bellis SL (2003) Ras oncogene directs expression of a differentially sialylated, functionally altered $\beta 1$ integrin. Oncogene 22: 7137-7145.

Seales EC, Jurado GA, Brunson BA, Wakefield JK, Frost AR, Bellis SL (2005) Hypersialylation of $\beta 1$ integrins, observed in colon adenocarcinoma, may contribute to cancer progression by up-regulating cell motility. Cancer Res 65: 4645-4652.

Shah MH, Telang SD, Shah PM, Patel PS (2008) Tissue and serum $\alpha 2-3$ - and $\alpha 2-6$-linkage specific sialylation changes in oral carcinogenesis. Glycoconj J 25: 279-290.

Siddiqui SF, Pawelek J, Handerson T, Lin C-Y, Dickson RB, Rimm DL, Camp RL (2005) Coexpression of $\beta 1,6-\mathrm{N}$ acetylglucosaminyltransferase $\mathrm{V}$ glycoprotein substrates defines aggressive breast cancers with poor outcome. Cancer Epidemiol Biomarkers Prev 14: 2517-2523.

Sturm RA, Satyamoorthy K, Meier F, Gardiner BB, Smit DJ, Vaidya B, Herlyn M (2002) Osteonectin/SPARC induction by ectopic 3 integrin in human radial growth phase primary melanoma cells. Cancer Res 62: 226-232.

Swindall AF, Bellis SL (2011) Sialylation of the Fas death receptor by ST6Gal-I provides protection against Fas-mediated apoptosis in colon carcinoma cells. J Biol Chem 286: 22982-22990. doi: 10.1074/jbc. M110.211375.

Szajda SD, Jankowska A, Zwierz K (2008) Carbohydrate markers in colon carcinoma. Dis Markers 25: 233-242.

Tanaka F, Otake Y, Nakagawa T, Kawano Y, Miyahara R, Li M, Yanagihara K, Nakayama J, Fujimoto I, Ikenaka K, Wada H (2000) Expression of polysialic acid and STX, a human polysialyltransferase, is correlated with tumor progression in non-small cell lung cancer. Cancer Res 60: 3072-3080.

Taniguchi A, Hioki M, Matsumoto K (2003) Transcriptional regulation of human Gal $\beta 1,3$ GalNAc/Gal $\beta 1,4$ Glc $\alpha 2,3$ sialyltransferase (hST4GalIV) gene in testis and ovary cell line. Biochim Biophys Res Commun 301: 764-768.

Thomas P (1996) Cell surface sialic acid as a mediator of metastatic potential in colorectal cancer. Cancer J 9: 1-10.

Varki A, Schauer R (2009) Sialic acids. In Essentials of Glycobioogy, Varki A, Cummings RD, Esko JD, Freeze HH, Stanley P, Bertozzi CR, Hart GW, Etzler ME eds, chapter 14. Cold Spring Harbor (NY). Varki NM, Varki A (2007) Diversity in cell surface sialic acid presenta-
tions: implications for biology and disease. Lab Invest 87: 851-857.

Vajaria BN, Patel KR, Begum R, Patel JB, Shah FD, Joshi GM, Patel PS (2014) Salivary glyco-sialylation changes monitors oral carcinogenesis. Glycoconj J 31: 649-659. doi: 10.1007/s10719-014-9561-7.

Videira PA, Correia M, Malagolini N, Crespo HJ, Ligeiro D, Calais FM, Trindade H, Dall'Olio F (2009) ST3Gal I sialyltransfer- 
ase relevance in bladder cancer tissues and cell lines. BMC Cancer doi:10.1186/1471-2407-9-357.

Wang FL, Cui SX, Sun LP, Qu XJ, Xie YY, Zhou L, Mu YL, Tang W, Wang YS (2009) Higher expression of $\alpha 2,3$-sialic acid residues is associated with the metastatic potential of human gastric cancer. Cancer Detect Prev 32: 437-443. doi: 10.1016/j.cdp.2009.01.001.

Wang PH (2005a) Altered glycosylation in cancer: sialic acids and sialyltransferases. I Cancer Mol 1: 73-81.

Wang PH, Lee WL, Juang CM, Yang YH, Lo WH, Lai CR, Hsieh SL, Yuan CC (2005b) Altered mRNA expressions of sialyltransferases in ovarian cancers. Gynecol Oncol 99: 631-639.

Westermark B, Johnsson A, Betsholtz C, Heldin CH, Herlyn M, Rodeck U, Koprowski H (1986) Human melanoma cell lines of primary and metastatic origin express the gene encoding the chains of platelet-derived growth factor (PDGF) and produce PDGF-like growth factor. Proc Natl Acad Sci USA 83: 7197-7200.

Xu L, Kurusu Y, Takizawa K, Tanaka J, Matsumoto K, Taniguchi A (2003) Transcriptional regulation of human $\beta$-galactoside $\alpha 2,6$ - sialyltransferase (hST6Gal I) gene in colon adenocarcinoma cell line. Biochem Biophys Res Commun 307: 1070-1074.

Yamamoto H, Saito T, Kaneko Y, Kersey D, Yong VW, Bremer EG, Mkrdichian E, Cerullo L, Leestma J, Moskal JR (1997) $\alpha 2,3$ sialyltransferase mRNA and $\alpha 2,3$-linked glycoprotein sialylation are increased in malignant gliomas. Brain Res 755: 175-179.

Zhao YY, Takahashi M, Gu JG, Miyoshi E, Matsumoto A, Kitazume S, Taniguchi N (2008) Functional roles of N-glycans in cell signaling and cell adhesion in cancer. Cancer Sci 99: 1304-1310. doi: 10.1111/j.1349-7006.2008.00839.x.

Zhang Y, Zhao J, Zhang X, Guo H, Liu F, Chen H (2004) Relations of the type and branch of surface N-glycans to cell adhesion, migration and integrin expressions. Mol Cell Biochem 260: 137-146.

Zhang M, Koskie K, Ross JS, Kayser KJ, Caple MV (2009) Enhancing glycoprotein sialylation by targeted gene silencing in mammalian cells. Biotechnol Bioeng 105: 1094-105. doi: 10.1002/bit.22633. 